\title{
Research Article \\ RELATIONSHIP OF TEMPERATURE ON WHEAT GROWTH, DEVELOPMENT AND YIELD UNDER MIDDLE GUJARAT AGRO-CLIMATIC REGION
}

\author{
SUTHAR B. M. , AHIR H. K. and PATEL H. R. \\ Department of Agricultural Meteorology, B. A. College of Agriculture, Anand Agricultural University, Anand, 388110, Gujarat, India. \\ *Corresponding Author: Email-bharti.suthar@yahoo.co.in
}

Received: January 31, 2018; Revised: February 24, 2018; Accepted: February 25, 2018; Published: February 28, 2018

\begin{abstract}
The field experiments were carried out at Anand Agricultural University, Anand, Gujarat, India during two consecutive rabi seasons of 2012-2014. The experiment was consisted of four dates of sowing (1 st Nov., $15^{\text {th }}$ Nov., 30th Nov. and 15th Dec.) with four varieties (V 1 : GW-322, V V: GW-496, V3: GW-366 (aestivum) and $V_{4}$ : GW-1139 (durum) and six irrigations at wheat phenophases under split plot design with the objective of assessment of influence of temperature on wheat phenology and grain yield. Tmax $\leq 30^{\circ} \mathrm{C}, \operatorname{Tmin} \leq 15^{\circ} \mathrm{C}$ increased the wheat phenological duration. Tmax $>30^{\circ} \mathrm{C}, \mathrm{Tmin}>17^{\circ} \mathrm{C}, \mathrm{T}$ mean $>24^{\circ} \mathrm{C}$ pre vailed during dough stage under $D_{4}$ sowing shrinked the reproductive phase. More vegetative days (66 to 72 ) and Tmin. between 9 to $10^{\circ} \mathrm{C}$ during booting stage coincide under $D_{2}$ and $D_{3}$ sowing which significantly increased the grain yield.
\end{abstract}

Keywords- Temperature, Phenology, Sowing date, Vegetative days, Grain yield.

Citation: Suthar B. M., et al., (2018) Relationship of Temperature on Wheat Growth, Development and Yield under Middle Gujarat Agro-Climatic Region. International Journal of Agriculture Sciences, ISSN: 0975-3710 \& E-ISSN: 0975-9107, Volume 10, Issue 4, pp.-5216-5219.

Copyright: Copyright@2018 Suthar B. M., et al., This is an open-access article distributed under the terms of the Creative Commons Attribution License, which permits unrestricted use, distribution and reproduction in any medium, provided the original author and source are credited.

Academic Editor / Reviewer: A. B. Gosavi, Dr Annu Verma

\section{Introduction}

Environmental conditions and agronomical practices like dates of sowing and suitable cultivars determined crop phenology and final yield. Effect of early, normal, late and very late planting on phenology and grain yield are vary with different cultivar. Temperature is a modifier factor in all stages of wheat growth, development including emergence (EM), crown root initiation (CRI), tillering (TL), booting (BT), flowering (FL), milking (ML) and dough (PM) that can governs the rate of water supply and other substrates necessary for growth and development but varies with plant species, variety and phenological stages [1]. Crop completes its life cycle much faster under higher temperature than normal temperature conditions [2-5].

Late or very late sowing in a sub-tropical region such as Pakistan, India, Bangladesh, etc. reduced plant height, duration of vegetative days, duration of grain filling, days to maturity, days to harvest and ultimately reduced yield and yield components. Under very late planting wheat crop experiences higher temperature during grain filling period which reduce the reproductive duration and less conversion of photosynthetes into grain yield. Reduction of grain filling period decreases grain size or shrink grain resultant reduces test weight. Under late or very late sowing initial lower temperature prolong the vegetative period which enhance the leaf area and dry matter of crop but heat stress during grain filling duration eventually decrease the grain yield. Optimum sowing time and selection of cultivar is the key factor for getting potential grain yield of wheat. Under delay sowing where heat stress coincides with reproductive phase, selection of short duration grain filling cultivar giving more produce by escaping heat stress in grain filling phase.

This study examined the variation of spring wheat phenological development in different dates of sowing under middle Gujarat agro-climatic zone. Phenology of wheat and grain yield correlated with temperature to discover how it affected on phenological development and its impact on grain yield.

\section{Materials and Methods}

Experimental site

Field investigation carried out at Agronomy farm, B. A. College of agriculture, Anand Agricultural University, Anand, (Lat. 22 $35^{\prime}$, Log. $72^{\circ} 55^{\prime}, 45.1 \mathrm{~m}$ from msl) during two consecutive rabi seasons of 2012-2014. The experiment was carried out with four dates of sowing (1 ${ }^{\text {st }}$ Nov., $15^{\text {th }}$ Nov., $30^{\text {th }}$ Nov. and $15^{\text {th }}$ Dec.) with four varieties (V1: GW-322, V2: GW-496, V: GW-366 (aestivum) and $V_{4}:$ GW-1139 (durum) under split plot design with six irrigation at each phenophases.

\section{Phenological observations:}

Based on the observations on individual plants at alternate day interval, occurrence of different phenological events viz., emergence, crown root initiation, tillering, booting, flowering, milking, dough stage and physiological maturity were demarcated [6]. When $50 \%$ of the plants on a plot reached the particular event, that day was reckoned as the day of the onset of that event.

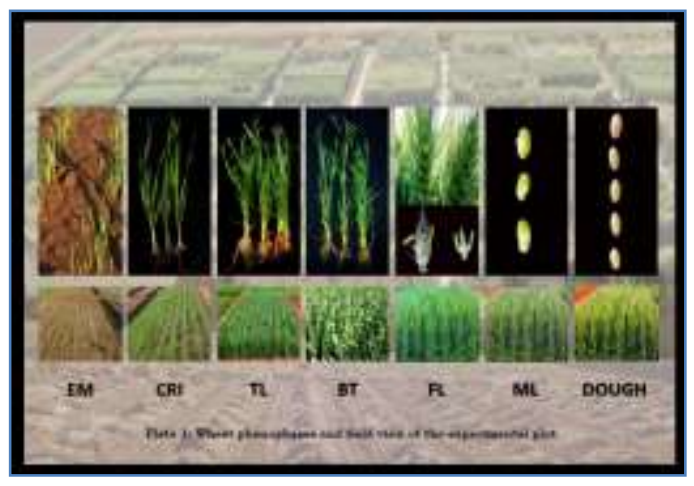




\section{Correlation and regression studies}

Correlation and regression studies were worked out by using SPSS 17, to check the effect of temperature on the phenological development and grain yield under different dates of sowing for all the varieties

\section{Results and discussion}

\section{Phenological variation under different treatments}

The varied environmental conditions and its effect on wheat phenological duration is presented in [Table-1] and discussed below.

\section{Emergence (EM):}

Wheat emergence took place on $6^{\text {th }}$ day under $D_{1}$ to $D_{3}$ sowings during 2012-13 and it was on $8^{\text {th }}$ day during 2013-14. In $D_{4}$ sowing it took more days (9) for emergence. $T$ mean $>22^{\circ} \mathrm{C}$ prevailed under $D_{1}$ to $D_{3}$ sowing [Fig-3] which decreased the emergence days during $2012-13$ and $T$ mean $\angle 22^{\circ} \mathrm{C}$ prevailed under $D_{4}$ sowing during 2013-14 increased the emergence days. These findings are agreed with in wheat [7].

\begin{tabular}{|c|c|c|c|c|c|c|c|}
\hline \multicolumn{8}{|c|}{ Table-1 Phenological calendar of dates of sowing } \\
\hline \multirow{2}{*}{ DOS } & \multicolumn{7}{|c|}{ Number of days required to attain } \\
\hline & EM & CRI & TL & BT & FL & ML & Dough \\
\hline \multicolumn{8}{|c|}{ Year 2012-13 } \\
\hline$D_{1}$ & 6 & 19 & 40 & 56 & 73 & 89 & 102 \\
\hline $\mathrm{D}_{2}$ & 6 & 18 & 42 & 60 & 76 & 88 & 101 \\
\hline $\mathrm{D}_{3}$ & 6 & 18 & 44 & 67 & 78 & 90 & 104 \\
\hline$D_{4}$ & 8 & 20 & 46 & 67 & 76 & 87 & 94 \\
\hline \multicolumn{8}{|c|}{ Year 2013-14 } \\
\hline$D_{1}$ & 8 & 21 & 43 & 57 & 73 & 88 & 97 \\
\hline $\mathrm{D}_{2}$ & 8 & 24 & 45 & 60 & 74 & 86 & 98 \\
\hline$D_{3}$ & 8 & 20 & 44 & 57 & 73 & 80 & 94 \\
\hline$D_{4}$ & 9 & 22 & 44 & 60 & 72 & 79 & 91 \\
\hline
\end{tabular}

\section{Crown root initiation (CRI):}

During both the crop growing seasons, crown root initiation duration ranged between 18 to 24 days. $\operatorname{Tmax}<31^{\circ} \mathrm{C}, \mathrm{Tmin}<15^{\circ} \mathrm{C}$ and $T$ mean $<23^{\circ} \mathrm{C}$ increase the days to attain crown root initiation stage.

\section{Tillering Stage (TL):}

During both the individual years 40 to 46 days required for attaining tillering phase. Lower temperature $\left(\operatorname{Tmax}<31^{\circ} \mathrm{C}\right.$, Tmin $<14^{\circ} \mathrm{C}$, T mean $\leq 20^{\circ} \mathrm{C}$ ) significantly increased the days required to attain tillering stage (44 to 46) under $D_{3}$ and $D_{4}$ sowings during both the years [Fig-1].

\section{Booting stage (BT):}

The days for attaining booting stage were observed at 56 to 67 days. Higher days (67) were recorded under $D_{3}$ and $D_{4}$ sowing, while lower days (56) recorded under $D_{1}$ sowing during first year. During second year, higher days (60) were observed under $D_{4}$ and $D_{2}$ sowings and lower days $(57)$ were recorded under $D_{1}$ and $D_{3}$ sowings. Tmax $\angle 30^{\circ} \mathrm{C}, \operatorname{Tmin} \leq 12^{\circ} \mathrm{C}, \mathrm{T}$ mean $\leq 22^{\circ} \mathrm{C}$ increase the days required to booting stage.

\section{Flowering stage (FL):}

During first year higher numbers of days (78) were required to attain flowering stage under $D_{3}$ sowing while lower days (73) were recorded in $D_{1}$ sowing. In second year higher numbers of days (74) were required to attain flowering stage under $\mathrm{D}_{2}$ sowing and lower days $(72)$ were recorded under $\mathrm{D}_{4}$ sowing. Tmax < $28^{\circ} \mathrm{C}$, Tmin $<15^{\circ} \mathrm{C}$, T mean $\leq 22^{\circ} \mathrm{C}$ increase the days to attain flowering stage. Overall on an average higher numbers of days (75) were required for attaining flowering stage under $D_{2}$ and $D_{3}$ sowing which significantly increase the grain yield.

\section{Milking Stage (ML):}

During both the years, higher number of days required for attaining milking stage and varied under different dates of sowing. Higher numbers of days (90) were required for attaining milking stage under $\mathrm{D}_{3}$ sowing and lower numbers of days
(87) were recorded under $D_{4}$ sowing. During second year of experimentation, higher number of days (88) was required for milking stage under $D_{1}$ sowing and lower number of days $(79)$ was recorded under $\mathrm{D}_{4}$ sowing.

It was observed that more number of days required for attaining milking stage as attained under $D_{1}$ sowing due to prevalence of lower temperature (Tmax. $\leq 28^{\circ} \mathrm{C}$, [Fig-1]. Similarly, lowest number of days was recorded under $D_{4}$ sowing due to prevalence of higher temperature (Tmax. $\geq 30^{\circ} \mathrm{C}$, [Fig-1].

\section{Dough stage (PM):}

Higher numbers of days (104) were required to attain dough stage under $D_{3}$ sowing and less number of days (94) were required under $D_{4}$ sowing during first year. In case of second year, more number of days (98) were required to attain dough stage under $D_{2}$ sowing and lower number of days (91) were required to attain dough stage under $\mathrm{D}_{4}$ sowing.

Higher temperature ( $\operatorname{Tmax} \geq 30^{\circ} \mathrm{C}, \operatorname{Tmin} \geq 16^{\circ} \mathrm{C}$ T mean $\geq 24^{\circ} \mathrm{C}$ ) prevailed during dough stage under $D_{4}$ sowing [Fig-3], which decreased the number of days to attain dough stage.
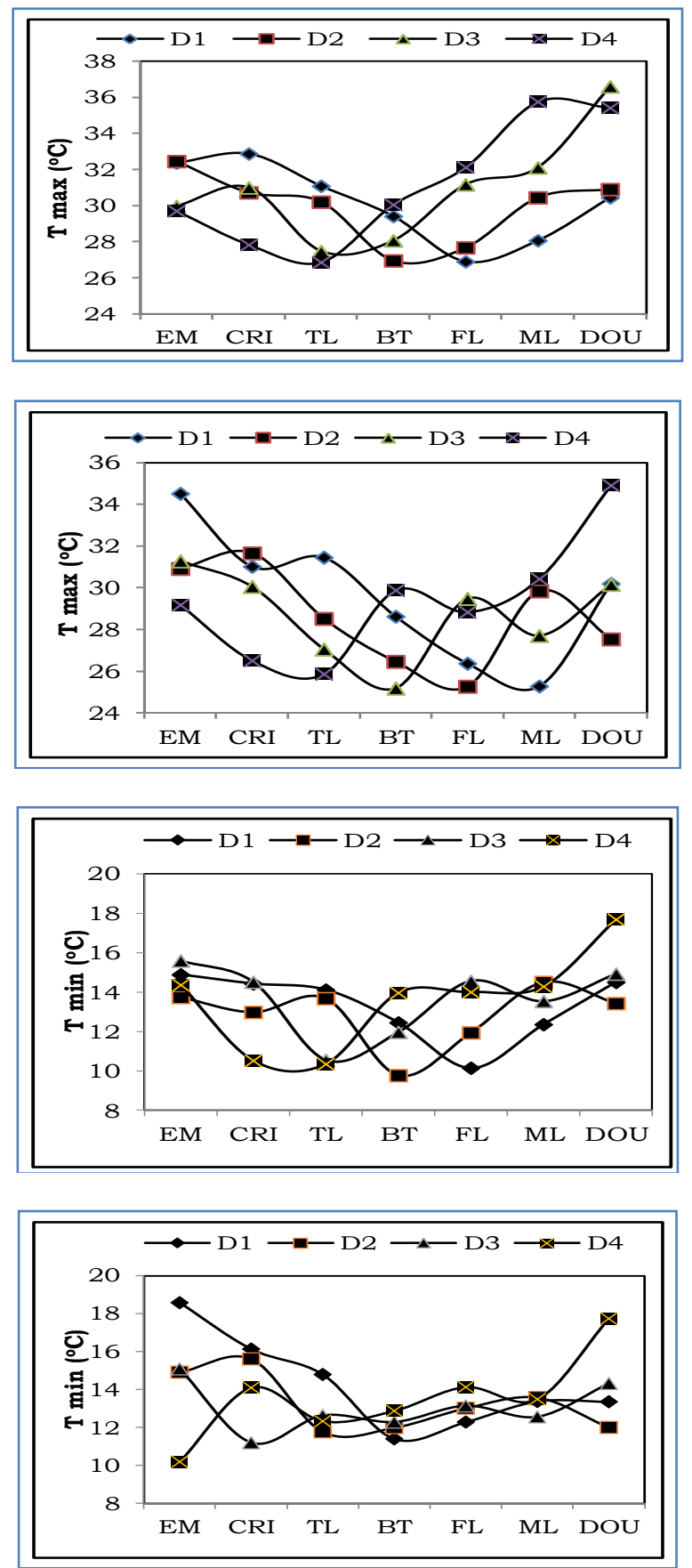


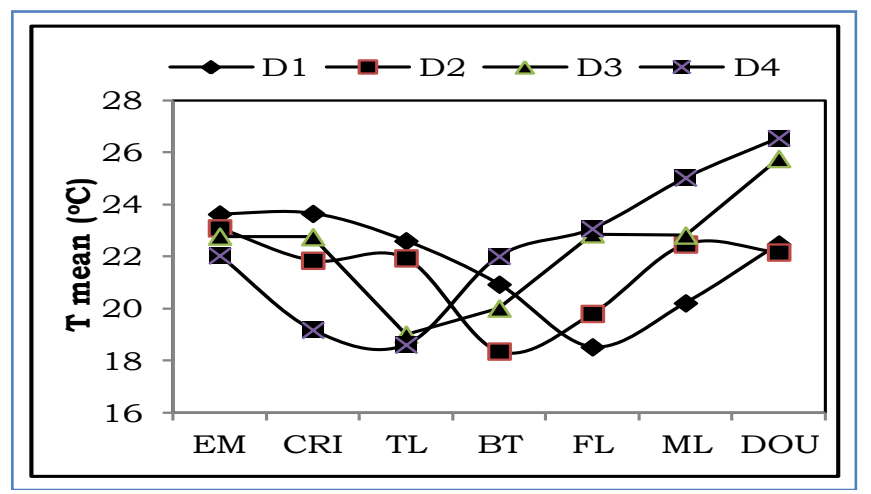

(2012-13)

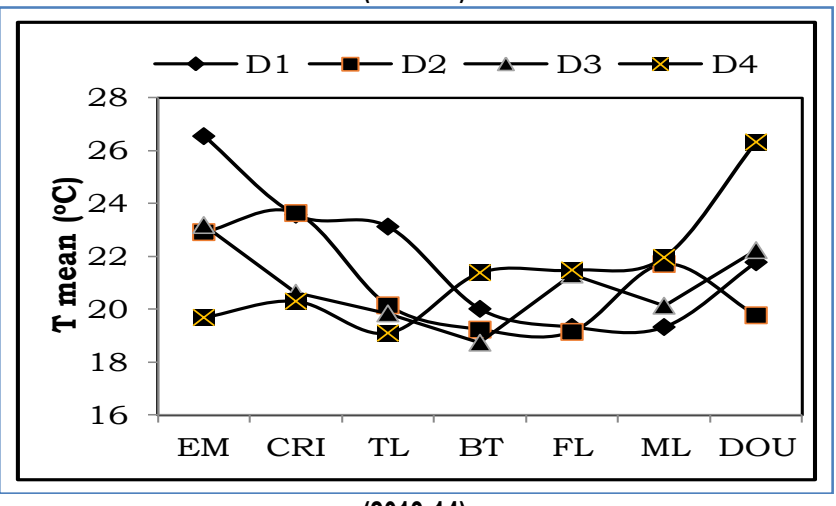

(2013-14)

Fig-1 Phase wise variation of maximum, minimum and mean temperature under different environmental condition of wheat during 2012-13 and 201314

Relationship between Tmin. prevailed during booting stage and grain yield The relationship between Tmin. at booting stage and grain yield is depicted in [Fig-2]. Result showed that grain yield and booting stage Tmin. linearly and negatively correlated. Tmin. 9 to $10^{\circ} \mathrm{C}$ during booting stage significantly increased the grain yield.. During 2012-13 year, booting stage Tmin. was prevailed in booting stage was 9 to $10^{\circ} \mathrm{C}$ under $D_{2}$ and $D_{3}$ sowing which significantly increased the grain yield and that was more than $5200 \mathrm{~kg} / \mathrm{ha}$. While during 2013-14 year, booting stage Tmin. $11^{\circ} \mathrm{C}$ prevailed under $D_{2}$ and $D_{3}$ sowing which significantly reduced (8\%) grain yield as compared to 2012-13. This is the reason behind the more grain yield was recorded under $D_{2}$ and $D_{3}$ sowing during 2012-13. On an average Tmin. increase 3 to $4^{\circ} \mathrm{C}$ from 10 to $11^{\circ} \mathrm{C}$ under $D_{1}$ and $D_{4}$ sowing which significantly reduced $10 \%$ grain yield than $D_{2}$ and $D_{3}$ sowing. These findings are confirmed with the findings of [8-10].

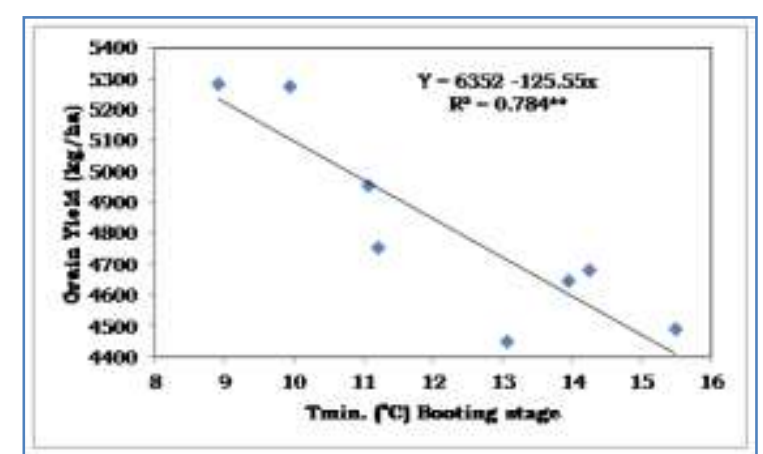

Fig-2 Relationship between Tmin. and grain yield during booting stage

\section{Relationship studies between vegetative days and grain yield}

The relationship between vegetative days and grain yield is depicted in [Fig-3] Results revealed that significant linear relationship was observed between vegetative days and grain yield. Higher vegetative days in the range of 66 to 72 under $D_{2}$ and $D_{3}$ sowing significantly increased the grain yield under both the individual year. This finding is confirmed with [9]. It might be more conversion of photosynthates in to carbohydrate of reproductive parts and there by grain yield. In general higher vegetative days (70 to 72 days) were recorded under $D_{2}$ and $D_{3}$ sowing during 2012-13 which significantly increased the grain yield as compared to $2013-14$.

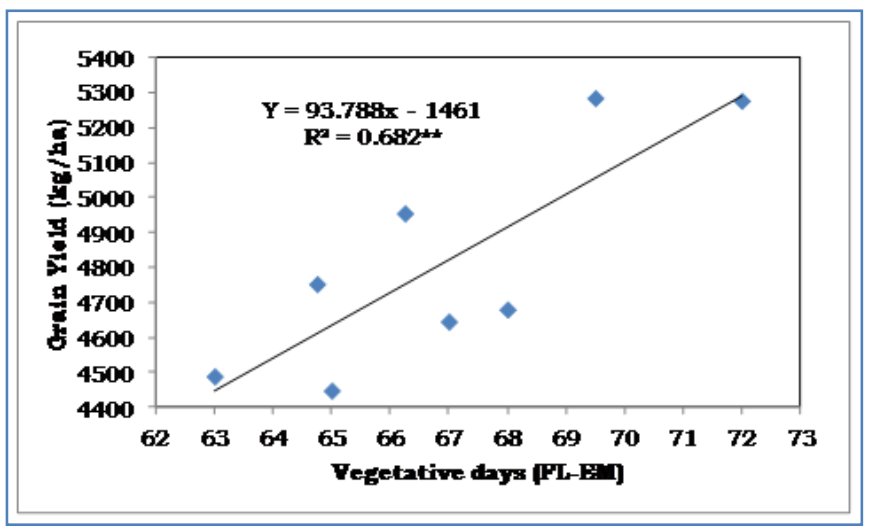

Fig-3 Relationship between vegetative days and grain yield

Temperature threshold for higher production of wheat

Result revealed that temperature threshold value (Table 2.) significantly increased vegetative days (66 to 72 ) and lower temperature during reproductive phase (FL, $M L$ and Dough) favoured higher production under $D_{2}$ and $D_{3}$ sowing.

Table-2 Temperature threshold for higher production of spring wheat

\begin{tabular}{|c|c|c|c|c|c|c|}
\hline \multirow{2}{*}{ Temperature } & \multicolumn{7}{|c|}{ Wheat Phenology } \\
\cline { 2 - 7 } & $\mathrm{EM}$ & $\mathrm{TL}$ & $\mathrm{BT}$ & $\mathrm{FL}$ & $\mathrm{ML}$ & Dough \\
\hline Tmax. & $\leq 31^{\circ} \mathrm{C}$ & $\leq 32^{\circ} \mathrm{C}$ & $\leq 29^{\circ} \mathrm{C}$ & $\leq 27^{\circ} \mathrm{C}$ & $\leq 29^{\circ} \mathrm{C}$ & $\leq 29^{\circ} \mathrm{C}$ \\
\hline Tmin. & $\leq 15^{\circ} \mathrm{C}$ & $\leq 16^{\circ} \mathrm{C}$ & $\leq 12^{\circ} \mathrm{C}$ & $\leq 13^{\circ} \mathrm{C}$ & $\leq 14^{\circ} \mathrm{C}$ & $\leq 13^{\circ} \mathrm{C}$ \\
\hline
\end{tabular}

\section{Conclusion}

$\checkmark T \operatorname{Tmax} \leq 31^{\circ} \mathrm{C}$ increase the days required to emergence, crown root initiation, tillering, booting, milking and dough while $\operatorname{Tmax} \leq 28^{\circ} \mathrm{C}$ increase the flowering days.

$\checkmark \quad T$ min $\leq 15^{\circ} \mathrm{C}$ increase the emergence, crown root initiation, flowering and milking stage.

$\checkmark$ Minimum temperature $\leq 14^{\circ} \mathrm{C}, \leq 12^{\circ} \mathrm{C}$ and $\leq 17^{\circ} \mathrm{C}$ increase the days required to tillering, booting and dough stage, respective.

$\checkmark \quad$ Higher temperature $\left(\operatorname{Tmax}>30^{\circ} \mathrm{C}, \mathrm{Tmin}>17^{\circ} \mathrm{C}, \mathrm{T}\right.$ mean $>24^{\circ} \mathrm{C}$ ) prevailed during dough stage under $D_{4}$ sowing decreased the number of days (91) to attain dough stage.

$\checkmark \quad D_{2}$ and $D_{3}$ sowing times found to be most optimum for higher production because more vegetative days and Tmin. 9 to $10^{\circ} \mathrm{C}$ during booting stage coincided which significantly increased the grain yield.

Application: Research finding will be useful for setting of sowing windows at different environmental location to adjust favorable temperature during phenophases for more produce.

\section{Research Category: Environmental conditions and agronomical practices}

Abbreviations: DOS- Date of Sowing, EM- Emergence Stage, CRI-Crown Root Initiation Stage, TL- Tillering Stage, BT-Booting Stage, FL- Flowering Stage, MLMilking Stage, Dough- Physiological Maturity Stage, Tmin.-Minimum Temperature, T max- Maximum Temperature, $\mathrm{T}$ mean- Mean Temperature, ${ }^{\circ} \mathrm{C}$ Degree Centigrade, D1-1 st Nov., D2-1 $5^{\text {th }}$ Nov., D $3-30^{\text {th }}$ Nov., D $4-15^{\text {th }}$ Dec.

Acknowledgement/Funding: Authors are thankful to Anand Agricultural University, Anand, 388110, Gujarat and AICRPAM- All India Coordinated Research Project on Agrometeorology.

Authors Contribution: All authors have equally contributed. 


\section{*Principle Investigator: Dr H.R. Patel}

University: Anand Agricultural University, Anand, 388110, Gujarat

Research Project name or number: AICRPAM

\section{References}

[1] Wahid A., Gelani S., Ashraf M. and Foolad M.R. (2007) Environ Exp Bot., 61, 199-233.

[2] Fischer R.A. (1985) In: Proc. Inter. Symp. on Physiological Limitations to Producing Wheat in Subtropical and Tropical Environments and Possible Selection Criteria held at CIMMYT, Maxico, pp. 290-330.

[3] Hakim M.A., Hossain A., Teixeira da Silva J.A., Zvolinsky V.P. and Khan M.M. (2012) J Sci Res., 4 (2), 477-489.

[4] Hossain A., Sarker M.A.Z., Hakim M.A., Lozovskaya M.V. and Zvolinsky V.P. (2011) Int J Agril Res Innov and Tech., 1 (1), 44-54.

[5] Rahman M.A., Chikushi J., Yoshida S. and Karim A.J.M.S. (2009) Bangla J Agril Res., 34 (3), 361-372.

[6] Zadoks J.C., Chang T.T. and Konzak C.F. (1974) Weed Res., 14, 415-421.

[7] Hossain A., Jaime A. T. S., Maria V. L. and Viacheslav P. Z. (2012) The Asian and Aust. Jour. of Plant Sci. and Bio., 6 (1), 14 - 23.

[8] Akhtar M., Cheema M.S., Moazzam J. and Ali L. (2006) Journal of Agricultural Research., 44, 255-261.

[9] Arain M.A., Ahmad M. and Rajput M.A. (1999) Evaluation of wheat genotypes under varying environments induced through changing sowing dates. Proc. Symp. New Genetical Approaches to Crop Improvement-III. Nuclear Institute of Agriculture, Tando Jam,Pakistan, pp.163-173.

[10] Sial M.A., Arain M.A., Khanzada S.D., Naqvi M.H., Dahot M.U. and Nizamani N.A. (2005) Pak. J. Bot., 37 (3), 575-584. 